\title{
ISOLASI DAN IDENTIFIKASI GOLONGAN KIMIA AKTIF ANTIOKSIDAN EKSTRAK ETANOL DAUN JAMBU METE (Anacardium occidentale L.)
}

\author{
A. Amaliah Dahlia ${ }^{1}$, Hasnawati \\ Laboratorium Farmakognosi Fitokimia \\ Universitas Muslim Indonesia \\ 1dahliaamalia@yahoo.co.id
}

\begin{abstract}
Has been carried out isolation and identification of active chemical groups ethanol extract antioxidant Cashew Leaves (Anacardium occidentale L.) in aims is determine the class of the active antioxidant compounds from ethanol extract of Cashew Leaves (Anacardium occidentale L.). Sample of 400 grams of macerated with ethanol produces dry extract 20.087 grams. Dry done profile TLC plate and then eluted with eluent n-hexane: ethyl acetate (6:4), and then sprayed DPPH to determine antioxidant compounds. Ethanol extracts was than isolated using vacum liquid chromatography column with n-exane, eluent ratio of n-hexane: ethyl acetate (9:1,8:2,7:3, 6:4, 5:5, 4:6, 3: 7, 2:8, 1:9) and ethyl acetate. XI fractions obtained, then sprayed with DPPH fraction VI showed the most intense antioxidant activity. Results isolates obtained were then identified using $u v$-vis spectroscopy showed maximum absorption at a wavelength of $424.50 \mathrm{~nm}$, Infrared spectroscopy showed absorbance at wave number $3393.18 \mathrm{~cm}-1$ shows possibility the $O$ - $H$ group reinforced the wave number 1102.20 which indicates the possibility of a $C$-O group, te wave number $2923,44 \mathrm{~cm}^{-1}$ shows possibility the $C-H$ (aromatic), the wave number $1555.13 \mathrm{~cm}-1$ which indicates the possibility of a cluster $C=C$, as well as identification by using specific reagents. From the above observations indicate that isolates classes of flavonoids suspected.
\end{abstract}

Keywords : Isolation, Cashew Leaves (Anacardium occidentale L.), Antioxidant, 2,2-diphenyl-1picrylhydrazyl.

\section{PENDAHULUAN}

\section{Latar Belakang}

Antioksidan adalah zat penghambat reaksi oksidasi akibat radikal bebas yang dapat menyebabkan kerusakan asam lemak tak jenuh sehingga menimbulkan penyakit. Senyawa antioksidan ini dapat diperoleh dari bahan alami, seperti Daun Jambu Mete (DJM). Antioksidan alami mampu melindungi tubuh terhadap kerusakan yang disebabkan spesies oksigen reaktif, mampu menghambat terjadinya penyakit degeneratif serta mampu menghambat peroksida lipid pada makanan (Subeki, 1998).

Daun Jambu Mete memiliki beberapa khasiat diantaranya sebagai obat luka bakar, diare, penyakit kulit, hipertensi dan diabetes melitus (Sugeng, 2009). Daun Jambu Mete mengandung senyawa golongan tanin jenis katekin dan pirokatekol, flavonoid jenis kuersetin 3-ramnosida (kuersitrosida), kuersetin 3-glukosida (isokuersitrosida), dan kuersetin 3-galloil-glukosida (Paris et al., 1977). Penelitian lain melaporkan daun
Jambu Mete mengandung steroid/triterpenoid, flavonoid, tanin, kuinon, dan saponin (Syaharuddin dkk, 1996).

Flavonoid dan fenolik tersebar luas dalam tanaman dan mempunyai efek biologis yang beragam. Hasil penelitian (Nugroho et al., 2013) menunjukkan bahwa kadar fenolik total ekstrak terpurifikasi daun Jambu Mete adalah $19,78 \pm 0,62 \%$, yang berarti setiap 100 $\mathrm{g}$ berat kering ekstrak daun Jambu Mete mengandung fenolik total setara asam galat sebesar 19,78 $\pm 0,62$ g. Sedangkan (Andarwulan et al., 2012) melaporkan kadar fenolik total daun Jambu Mete segar setara asam galat hanya $847,41 \pm 15,05 \mathrm{mg} / 100 \mathrm{~g}$ berat basah atau $0,85 \mathrm{~g} / 100 \mathrm{~g}$ berat basah. Namun, kadar fenolik total ekstrak daun Jambu Mete lebih rendah dibanding hasil penelitian (Razali et al,. 2008) ekstrak metanolik pucuk/tunas daun Jambu Mete setara asam galat yaitu $307,3 \pm 0,11 \mathrm{mg} / \mathrm{g}$ atau $30,73 \mathrm{~g} / 100 \mathrm{~g}$ berat kering. Hal ini dapat dipengaruhi karena ekstrak daun Jambu Mete menggunakan daun yang lebih tua yang 
kemungkinan mempunyai senyawa tanin yang sudah berkurang.

Hasil penelitian (Nugroho et al., 2013) menunjukkan bahwa kadar flavonoid total ekstrak daun Jambu Mete rata-rata adalah $1,970 \pm 0,006 \%$ yang berarti setiap 100 $\mathrm{g}$ berat kering ekstrak daun Jambu Mete mengandung flavonoid total $1,970 \pm 0,006 \mathrm{~g}$. Hasil ini lebih besar jika dibandingkan hasil penelitian (Sulaiman et al., 2011) yang menggunakan ekstrak daun Jambu Mete dengan kandungan flavonoid total setara kuersetin hanya $9,3 \pm 0,6 \% \mathrm{mg} / \mathrm{g}$ berat kering ekstrak atau $0,93 \mathrm{~g} / 100 \mathrm{~g}$ berat kering ekstrak.

Sehubungan dengan hal tersebut, maka dalam penelitian ini akan dilakukan isolasi dan identifikasi untuk mengetahui golongan kimia yang aktif sebagai antioksidan dari ekstrak etanol daun Jambu Mete (EEDJM).

\section{METODE PENELITIAN}

\section{A. Pengambilan dan pengolahan sampel}

Sampel daun Jambu Mete diambil dari Dusun Cilellang Palanro, Kabupaten Barru Provinsi Sulawesi Selatan. Sampel daun Jambu Mete yang telah dikumpulkan, dicuci bersih menggunakan air mengalir, setelah itu dilakukan perajangan atau di potong-potong kecil. Selanjutnya dikeringkan dengan cara diangin-anginkan tanpa paparan sinar matahari langsung.

\section{B. Ekstraksi sampel}

1. Maserasi dengan pelarut etanol

Daun Jambu Mete ditimbang sebanyak 400 gram, dimasukkan ke dalam wadah maserasi, dan ditambahkan pelarut etanol sebanyak $4000 \mathrm{~mL}$ hingga simplisia tersebut terendam, dibiarkan selama 3 hari dalam bejana tertutup sambil diaduk secara periodik. Setelah 3 x 24 jam dilakukan penyaringan dan diperoleh ekstrak etanol cair. Proses maserasi diulang sampai 3 kali. Hasil penyarian yang diperoleh kemudian diuapkan dengan menggunakan rotavapor sehingga akan diperoleh ekstrak kental. Ekstrak etanol kental diuapkan lagi hingga diperoleh ekstrak etanol kering sebanyak 20,087 gram.

\section{Uji antioksidan}

Ekstrak etanol daun Jambu Mete yang diperoleh diambil secukupnya, dimasukkan dalam vial kemudian ditambah dengan pelarut etanol. Selanjutnya ditotol pada lempeng KLT yang berukuran 1 x $7 \mathrm{~cm}$ dan dielusi dengan eluen $n$-heksan : etil asetat (6 : 4). Dilihat di UV 254 dan $366 \mathrm{~nm}$ dan diperoleh 5 noda, selanjutnya disemprot dengan DPPH sebagai langkah awal untuk mengetahui adanya senyawa yang aktif antioksidan, dari hasil semprot tersebut ekstrak etanol daun Jambu Mete mempunyai aktivitas antioksidan.

\section{Isolasi dan pemurnian senyawa kimia \\ a. Isolasi dengan metode kromatografi kolom cair vakum}

\section{Penyiapan kolom}

Kolom kromatografi berdiameter $6 \mathrm{~cm}$ dan panjang $30 \mathrm{~cm}$ dibersihkan dengan etanol kemudian disumbat bagian bawah kolom dengan kapas agar silika gel dapat memisahkan komponen kimia. Sebanyak 25 gram adsorben silika gel $60(0,2-0,5 \mathrm{~mm})$ berbanding 5 gram silika gel $60 \mathrm{GF}_{254}$ (Merck Germany) dicampurkan dengan eluen nheksan : etil asetat (6:4) yang digunakan, kemudian dimasukkan kedalam kolom dan dimampatkan secara perlahan sehingga diperoleh kerapatan kolom yang seragam.

\section{Isolasi sampel}

Ekstrak etanol daun Jambu Mete ditimbang sebanyak 1 gram, kemudian diletakkan diatas permukaan adsorben yang sebelumnya telah dimasukkan dalam kolom, diatas ekstrak tersebut diletakkan kertas saring. Setelah itu dimasukkan n-heksan, eluen $n$-heksan : etil asetat $(9: 1,8: 2,7: 3,6: 4$, 5:5, 4:6, 3:7, 2:8, 1:9) dan etil asetat, dialirkan dengan kecepatan $1 \mathrm{ml} /$ menit. Fraksi yang keluar ditampung dalam wadah dan diperoleh sebanyak 11 fraksi. Fraksi yang diperoleh diidentifikasi dengan KLT untuk melihat profil kromatogram. Dimana fraksi tersebut dilarutkan dengan pelarut etanol, kemudian ditotol pada lempeng KLT silica gel $60 \mathrm{~F}_{254}$ (Merck Germany) berukuran 1 x $7 \mathrm{~cm}$ menggunakan pipa kapiler dan dielusi dengan eluen n-heksan:etil asetat (6:4). Setelah itu, dilihat di UV 254 dan 366 selanjutnya disemprot dengan DPPH untuk mengetahui senyawa yang aktif antioksidan, dari hasil semprot tersebut, fraksi VI menunjukkan aktivitas antioksidan paling intens yang 
ditunjukkan dari perubahan warna ungu menjadi kuning (Sarker et al., 2006).

\section{b. Identifikasi dengan KLT preparatif}

Berdasarkan profil kromatogram, fraksi yang mempunyai aktivitas antioksidan paling intens yaitu fraksi VI. Sebelumnya fraksi dilarutkan dengan pelarut etanol kemudian ditotolkan pada lempeng KLT (Merck Germany) dengan ukuran yang lebih besar yaitu $10 \times 10 \mathrm{~cm}$ dengan menggunakan eluen $n$-heksan : etil asetat (6:4) dalam suatu bejana KLTP, setelah itu dideteksi menggunakan sinar UV 254 dan $366 \mathrm{~nm}$ dan diperoleh 7 pita. Lempeng yang telah diamati diberi tanda dan dikeruk. Hasil kerukan tersebut ditambahkan pelarut metanol kemudian disentrifuge, filtrat ditampung kemudian diuapkan hingga didapatkan isolat. Selanjutnya isolat yang diperoleh ditotol pada lempeng KLT (Merck Germany) dengan menggunakan eluen n-heksan : etil asetat (6:4), hasilnya disemprot dengan DPPH dan yang menunjukkan aktivitas antioksidan terdapat pada pita II.

\section{c. Uji kemurnian isolat aktif}

1. Elusi sistem dua dimensi

Isolat yang diperoleh dilarutkan dengan etanol kemudian ditotolkan pada lempeng KLT (Merck Germany) lalu dielusi dengan eluen n-heksan : etil asetat (7:3) arah pertama dan eluen n-heksan : etil asetat (8:2) untuk arah kedua, Selain itu juga digunakan eluen n-heksan : etil asetat (7:3) untuk arah pertama dan eluen n-heksan : aseton (7:3) untuk arah kedua. Proses elusi yang kedua dilakukan dengan cara memutar lempeng berlawanan dengan arah jarum jam sehingga hasil elusi yang pertama menjadi titik awal pengelusian yang kedua. Dari proses elusi yang dilakukan terdapat satu bercak tunggal, maka dapat diduga bahwa isolat tersebut adalah komponen kimia yang tunggal.

\section{Elusi sistem multi eluen}

Uji kemurnian isolat dilakukan dengan menggunakan beberapa variasi eluen yaitu n-heksan : etil asetat (7:3), n-heksan : aseton (9:1), dan kloroform : metanol (1:1). Penampakan bercak tunggal menandakan bahwa golongan senyawa dari bercak yang didapat merupakan golongan senyawa kimia yang tunggal.

\section{Identifikasi sampel}

\section{Identifikasi dengan pereaksi kimia}

Senyawa murni yang diperoleh, ditotolkan pada lempeng KLT dan di elusi. Hasil pengelusian kemudian disemprotkan dengan penampak bercak yaitu pereaksi sitroborat (flavonoid), aluminium klorida (flavonoid), $\mathrm{FeCl}_{3}$ (flavonoid dan tanin), Libermann-Bouchardat (tanin, flavonoid, steroid dan saponin).

\section{Identifikasi spektroskopi uv-vis}

Kristal murni yang diperoleh, diidentifikasi dengan spektroskopi UV-Vis. Senyawa dilarutkan dengan metanol kemudian cuplikan ditempatkan diantara monokromator dan detector. Spektrum yang dihasilkan direkam pada alat pencatat.

\section{Identifikasi spektroskopi infra merah}

Kristal murni yang diperoleh diidentifikasi dengan spektroskopi infra merah dengan cara menempatkan cuplikan sebagai film yang tipis diantara dua lapisan natrium klorida yang transparan, kemudian ditempatkan pada celah sinar infra merah. Hasil direkam pada alat pencatat.

\section{HASIL DAN PEMBAHASAN}

\section{A. HASIL PENELITIAN}

Sampel daun Jambu Mete sebanyak 400 gram diekstraksi secara maserasi yaitu menggunakan pelarut etanol sebanyak 4000 $\mathrm{mL}$, menghasilkan ekstrak etanol kental 20,087 gram.

Hasil profil ekstrak etanol secara kromatografi lapis tipis dengan menggunakan cairan pengelusi n-heksan :etil asetat (6:4), menunjukkan 1 bercak pada sinar UV $254 \mathrm{~nm}, 4$ bercak pada sinar UV $366 \mathrm{~nm}$, hasilnya disemprot dengan menggunakan DPPH untuk melihat senyawa yang mempunyai aktivitas antioksidan. Senyawa yang aktif antioksidan adalah noda dengan nilai Rf 0,54 yang menunjukkan perubahan warna dari ungu menjadi kuning (Sarker et al., 2006)

Ekstrak etanol daun Jambu Mete sebanyak 1 gram diisolasi secara kromatografi kolom cair vakum menggunakan campuran adsorben silika gel $60(0,2-0,5 \mathrm{~mm})$ sebanyak 25 gram dan silika gel $60 \mathrm{GF}_{254}$ sebanyak 5 gram dengan menggunakan cairan pengelusi n-heksan, etil asetat, eluen n-heksan : etil asetat (9:1, 8:2, 
7:3, 6:4, 5:5, 4:6, 3:7, 2:8, 1:9) menghasilkan 11 fraksi.

Dari hasil fraksi yang menunjukkan aktivitas antioksidan paling intens terdapat pada fraksi VI yang ditunjukkan dengan perubahan warna dari ungu menjadi kuning (Sarker et al., 2006).

Selanjutnya fraksi VI dari kromatografi kolom cair vakum ini diisolasi lagi secara kromatografi lapis tipis preparatif menggunakan eluen $n$-heksan:etil asetat (6:4) menghasilkan 7 pita. Profil kromatografi hasil KLT-Preparatif disemprot dengan menggunakan DPPH dan menunjukkan aktivitas antioksidan pada pita II, sehingga pita II yang kemudian dilanjutkan untuk uji kemurnian.

Isolat yang diperoleh dilarutkan kemudian ditotolkan pada lempeng silika gel $60 \mathrm{~F}_{254}$ (Merck Germany) dengan ukuran $5 \mathrm{x}$ $5 \mathrm{~cm}$. Lalu dielusi dengan eluen n-heksan : etil asetat (7:3) untuk arah pertama, dan nheksan : etil asetat (8:2) untuk proses elusi yang kedua, selain itu juga digunakan eluen n-heksan : etil asetat (7:3) untuk arah pertama dan n-heksan : aseton (7:3) untuk arah kedua, dilakukan dengan cara memutar lempeng berlawanan dengan arah jarum jam sehingga hasil elusi yang pertama menjadi titik awal pengelusian untuk yang kedua, dari proses elusi tersebut diperoleh satu bercak tunggal, maka dapat dikatakan bahwa isolat tersebut adalah komponen kimia yang tunggal. Uji kemurnian isolat juga dilakukan dengan menggunakan beberapa variasi eluen yaitu kloroform : metanol (1:1), n-heksan:etil asetat (7:3) dan n-heksan:aseton (9:1). Hasil elusi tersebut menampakkan noda tunggal pada UV $366 \mathrm{~nm}$.

Data spektroskopi ultravioletvisibel isolat pita II menunjukkan serapan maksimum pada panjang gelombang 424,50 nm. Menurut Farmakope Herbal Indonesia (2008) serapan flavonoid yaitu $425 \mathrm{~nm}$, sedangkan Markham (2006) menjelaskan bahwa panjang gelombang flavanoid berkisar 400-500 nm. Sedangkan data spektroskopi infra merah isolat pita II dengan data spektrum yaitu pada bilangan gelombang $3393,18 \mathrm{~cm}^{-1}$ menunjukkan adanya gugus $\mathrm{O}-$ $\mathrm{H}$ yang diperkuat dengan bilangan gelombang $1102,20 \mathrm{~cm}^{-1}$ yang menunjukkan adanya gugus $\mathrm{C}-\mathrm{O}$, pada bilangan gelombang $2923,44 \mathrm{~cm}^{-1}$ menunjukkan adanya gugus $\mathrm{C}-\mathrm{H}$ (aromatik) yang diperkuat dengan bilangan gelombang 1456,07 cm- ${ }^{1}$ yang menunjukkan adanya gugus $\mathrm{C}-\mathrm{C}$, pada bilangan gelombang $1555,13 \quad \mathrm{~cm}^{-1}$ menunjukkan adanya gugus $\mathrm{C}=\mathrm{C}$. Sedangkan menurut Asih (2008) golongan flavonoid pada spektrum infra merah akan menunjukkan adanya gugus $\mathrm{O}-\mathrm{H}, \mathrm{C}-\mathrm{H}, \mathrm{C}=\mathrm{C}$.

\begin{tabular}{|c|c|c|c|}
\hline \multicolumn{3}{|c|}{ Bilangan Gelombang } & \multirow[b]{2}{*}{$\begin{array}{c}\text { Prediksi } \\
\text { Gugus }\end{array}$} \\
\hline $\begin{array}{l}\text { Isolat } \\
\text { pita II }\end{array}$ & Pustaka & Peak & \\
\hline 3393,18 & $3000-3700$ & $\begin{array}{l}\text { Kuat, } \\
\text { Melebar }\end{array}$ & $\mathrm{O}-\mathrm{H}$ \\
\hline $\begin{array}{l}2923,44 \\
2791,48\end{array}$ & $\begin{array}{l}2800-3000 \\
2750-2850\end{array}$ & $\begin{array}{l}\text { Kuat } \\
\text { Puncak } \\
\text { lemah }\end{array}$ & $\mathrm{C}-\mathrm{H}$ \\
\hline $\begin{array}{l}1555,13 \\
1456,07 \\
1102,20\end{array}$ & $\begin{array}{c}1500-1900 \\
1450-1600 \\
900-1300\end{array}$ & Kuat & $\begin{array}{l}\mathrm{C}=\mathrm{C} \\
\mathrm{C}-\mathrm{C} \\
\mathrm{C}-\mathrm{O}\end{array}$ \\
\hline
\end{tabular}

Selanjutnya adalah identifikasi secara reaksi kimia yaitu dengan menggunakan pereaksi Liberman Bouchardat memberikan warna hitam (negatif untuk golongan steroid), pereaksi Sitroborat memberikan warna kuning kehijauan pada sinar tampak, berfluoresensi pada $\mathrm{UV}_{366}$ (positif untuk golongan flavonoid), peraksi $\mathrm{FeCl}_{3}$ memberikan warna hijau (positif untuk golongan fenolik), dan pereaksi aluminium klorida memberikan warna kuning pada sinar tampak (positif untuk golongan flavonoid).

\section{B. PEMBAHASAN}

Penelitian ini menggunakan daun Jambu Mete (DJM) dengan nama simplisia Anacardii Occidentalis Folium (Depkes RI, 2008) yang diambil dari Dusun Palanro Kabupaten Barru Sulawesi Selatan. Daun Jambu Mete dalam keadaan segar langsung dideterminasi di Laboratorium Farmakognosi-Fitokimia Fakultas Farmasi UMI. Determinasi sampel penelitian dilakukan untuk memastikan kebenaran bahan tanaman yang digunakan dan merupakan salah satu tahapan penting dalam proses selanjutnya. Hasil identifikasi tanaman menunjukkan bahwa sampel tersebut adalah jenis Anacardium occidentale L., dari suku Anacardiaceae (hasil identifikasi dapat dilihat pada lampiran). 
Berdasarkan hasil determinasi tersebut, maka sampel tanaman yang digunakan adalah benar yaitu jambu mete, dalam bahasa inggris disebut cashew. Dengan adanya kepastian identitas sampel, maka daun Jambu Mete diambil dalam jumlah yang lebih banyak kemudian dikeringkan dan diserbukkan untuk pengujian selanjutnya.

Simplisia daun Jambu Mete kering diekstraksi dalam bentuk serbuk untuk memudahkan proses penarikan senyawa aktif oleh pelarut dari dalam jaringan tumbuhan. Bentuk serbuk lebih mudah tersari karena luas kontak antara permukaan jaringan sel dengan pelarut lebih besar. Pelarut yang digunakan yaitu etanol $96 \%$ (Konan et al., 2010; Depkes RI, 2008). Pelarut ini disebut juga pelarut universal yang baik untuk ekstraksi pendahuluan karena kemampuan melarutkan senyawa-senyawa organik baik polar maupun nonpolar (Seidel, 2006; Harborne, 1987).

Metode ekstraksi daun Jambu Mete yang digunakan dalam penelitian ini adalah maserasi (Depkes RI, 2008) karena lebih sederhana, mudah dan tanpa pemanasan. Maserasi daun Jambu Mete menggunakan etanol $96 \%$ dilakukan selama 24 jam kemudian diremaserasi lagi dengan pelarut yang sama untuk menarik senyawa aktif agar diperoleh ekstrak yang lebih banyak. Menurut Depkes RI (2008), maserasi daun Jambu Mete sekurang-kurangnya 2 kali dengan jenis dan pelarut yang sama. Hasil maserasi diuapkan dengan rotavapor sampai diperoleh ekstrak agak kental. Penguapan ekstrak cair daun Jambu Mete dengan menggunakan rotavapor dapat menimbulkan floating mengingat adanya kandungan saponin dalam daun Jambu Mete, sehingga tekanan, putaran rotor dan suhu harus tetap terjaga. Hasil penguapan dengan rotavapor belum menunjukkan konsistensi yang kental, sehingga dilanjutkan dengan penguapan diatas tangas air sampai diperoleh ekstrak kental. Hasil ekstraksi diperoleh ekstrak etanol sebesar 20,087 gram dari berat serbuk kering daun Jambu Mete sebanyak 400 gram.

Dilakukan uji pendahuluan untuk mengetahui aktivitas antioksidan dari ekstrak etanol daun Jambu Mete dengan penyemprotan DPPH. Pada penelitian ini metode yang digunakan yaitu kromatografi kolom cair vakum karena metode ini dalam pengerjaan dan alat yang digunakan lebih sederhana, proses pengelusiannya cepat karena dibantu dengan pompa vakum, selain itu menggunakan tekanan yang rendah untuk meningkatkan laju aliran dari fase gerak (Hostmeen, 1995).

Senyawa yang lebih polar akan terikat kuat pada silika gel sedangkan senyawa yang nonpolar akan terelusi jauh oleh sistem pelarut seperti n-heksan : etil asetat (Oniszczuk dan Wojciak-Kosior, 2008). Penelitian ini menggunakan fase gerak n-heksan : etil asetat (6:4) modifikasi dari Oniszczuk dan Wojciak-Kosior (2008), karena dengan perbandingan tersebut telah mampu mengelusi senyawa sampai mendeteksi batas garis atas.

Senyawa yang mempunyai aktivitas antioksidan akan bereaksi dengan radikal DPPH yang berwarna ungu dan berubah menjadi senyawa yang lebih stabil menjadi warna kuning (Sarker et al., 2006). Sifat antioksidan dari flavonoid berasal dari kemampuannya untuk mentransfer sebuah elektron ke senyawa radikal bebas dan juga membentuk kompleks dengan logam, sehingga kedua mekanisme tersebut membuat flavonoid memiliki beberapa efek, diantaranya menghambat peroksidasi lipid, menekan kerusakan jaringan oleh radikal bebas dan menghambat aktivitas beberapa enzim ( Pietta, 2000).

Hasil yang diperoleh berdasarkan pengukuran menggunakan spektrofotometer uv-vis pada panjang gelombang $424,50 \mathrm{~nm}$, pada panjang gelombang inilah didapatkan nilai absorbansi terbesar yaitu 0,227 . Hal ini sesuai dengan literatur Farmakope Herbal Indonesia (2008), bahwa panjang gelombang $425 \mathrm{~nm}$ adalah golongan flavonoid, sedangkan menurut Markham (2006), serapan flavonoid berkisar 400-500 nm. Sedangkan data spektroskopi infra merah isolat pita II pada bilangan gelombang $3393,18 \mathrm{~cm}^{-1}$ menunjukkan adanya gugus $\mathrm{O}$ $\mathrm{H}$ yang diperkuat dengan bilangan gelombang $1102,20 \mathrm{~cm}^{-1}$ yang menunjukkan adanya gugus $\mathrm{C}-\mathrm{O}$, pada bilangan gelombang $2923,44 \mathrm{~cm}^{-1}$ menunjukkan adanya gugus $\mathrm{C}$ $\mathrm{H}$ (aromatik), yang diperkuat dengan bilangan gelombang $1456,07 \mathrm{~cm}^{-1}$ yang menunjukkan adanya gugus $\mathrm{C}-\mathrm{C}$, pada bilangan gelombang 1555,13 $\mathrm{cm}^{-1}$ menunjukkan adanya gugus $\mathrm{C}=\mathrm{C}$.

Berdasarkan profil KLT dan identifikasi diatas, maka dapat disimpulkan 
bahwa ekstrak etanol daun Jambu Mete adalah senyawa golongan flavonoid. Salah satu reagen spesifik untuk flavonoid adalah penampak bercak sitroborat yang digunakan untuk mendeteksi senyawa flavonoid dalam ekstrak etanol daun Jambu Mete dengan ciri berflouresensi pada UV $_{366}$ (Depkes RI, 2008).

Hasil ini mendukung penelitian bahwa daun Jambu Mete mengandung senyawa-senyawa fenolik dan polifenol (Syaharuddin dkk, 1996; Sulaiman et al., 2011; Depkes RI, 2008; Andarwulan et al., 2012). Paris et al.,(1977) melaporkan adanya senyawa flavonoid dalam ekstrak daun Jambu Mete jenis kuersetin 3-ramnosida, kuersetin-glukosida, dan kuersetin 3-galloilglukosida. Konan et al.,(2010) menemukan flavonoid jenis agatisflavon.

\section{KESIMPULAN}

Berdasarkan hasil penelitian yang telah dilakukan, maka dapat disimpulkan bahwa:

1. Senyawa aktif antioksidan dapat diisolasi dari ekstrak etanol daun Jambu Mete (Anacardium occidentale L.)

2. Golongan kimia yang aktif sebagai antioksidan berdasarkan data diatas adalah golongan flavonoid.

\section{DAFTAR PUSTAKA}

1. Andarwulan, N., Kurniasih, D., Apriady, R.A., Rahmat, H., Rotoc, A.V., and Bolling, B.W., 2012, "Polyphenols, Carotenoids, and Ascorbic Acid in Underutilized Medicinal Vegetables", ISNFF, Article in Press.

2. Depkes RI. 2008. "Farmakope Herbal Indonesia Edisi 1". Jakarta

3. Harborne, J.B.,1987, "Metode Fitokimia Penuntun Cara Modern Mengekstraksi Tumbuhan", terjemahan Padmawinata, K, Penerbit ITB : Bandung.

4. Hostettman, K. and Wolfender, J.L., 2011, "Aplication of Liquid Chromatography/UV/MS"., Bioactive Compounds from Natural Source Isolation, Taylor \& Francis, London, UK.
5. Konan, N.A., Lincopan, N., 2010, "Citotoxicity of Cashew Flavanoid" Towards Cell Lines, ESTP.

6. Markham, R. Andersen. M., 2006. "Flavanoids Chemistry, Biochemistry and Applications. London. New York.

7. Nugroho, A.E., Suhardjono, D., Mulyono, S.A, Malik, A., 2013 "Total Flavanoid and Fenolik Contents and in Vitro Antyhipertention Activity of Indonesia Cashew Leaves Anacardium occidentale L. Fakultas Farmasi. UGM. Yogyakarta.

8. Paris, R., Plat, M., Barber, P.G., Linhard, J., and Laurens, A., 1977, Receherce Chimique et Pharmacologique sur les Feuilles d'Anacardium occidentale L. (Anacardiaceae), Bull. Soc. Med. Afr

9. Pietta, P.G. 2000. "Journal Natural".Product".http://nfscfaculty.tam u.edu/talcott/Food Chem 605/Class Presentation Papers/Review Flavonoids as AOX.pdf. Y. Porat, A. Abramowitz.

10. Sarker., Zahid Latif., Alexander Gray., 2006, Natural Product Isolation $2^{\text {nd }}$ Humana Press Inc, Totowa, NJ.

11. Seidel, V. 2006. "Initial and Bulk Extraction, In Sarker, S.D., Latif, Z. And Gray, A. I., Natural Product Isolation, $2^{\text {nd }}$ edition, Humana Press Inc., Totowa, New Jersey.

12. Subeki, 1998. " Antioksidan Alami Terhadap Tumbuhan ." Kanisius : Yogyakarta.

13. Sugeng, H., 2009. "Ensiklopedia Tanaman Obat Indonesia".Yogyakarta.

14. Sulaiman, S.F., Sajak and S eow, E.M., 2011, Effect of Solvent in Extracting Polyphenola and Antioxidants of Selected. Food Compos. Anal.

15. Syaharuddin, Padmawinata, K., dan Soetarno, S., 1996, "Isolasi dan Penentuan Struktur Beberapa Senyawa Kimia dalam Daun Jambu Mete (Anacardium occidentale L., Anacardiaceae)”, ITB Bandung. 
16. Wojciak-Kosior, M. And Oniszczuk, A. 2008. Ample Preparation and TLC Analysis of Phenolic Acids, In Waksumundzka, Hajnos. M., Sherma, J., Kowalska, T., Thin Layer Chromatography in Phytocemistry, CRC Press Taylor and Prancis Group Boca Raton. 